

\section{State Clean Energy Policies Analysis (SCEPA): State Tax Incentives}

Eric Lantz and Elizabeth Doris

Prepared under Task No. IGST.9000

Technical Report NREL/TP-6A2-46567

October 2009

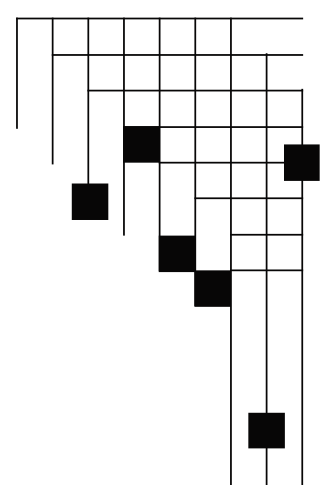




\section{NOTICE}

This report was prepared as an account of work sponsored by an agency of the United States government. Neither the United States government nor any agency thereof, nor any of their employees, makes any warranty, express or implied, or assumes any legal liability or responsibility for the accuracy, completeness, or usefulness of any information, apparatus, product, or process disclosed, or represents that its use would not infringe privately owned rights. Reference herein to any specific commercial product, process, or service by trade name, trademark, manufacturer, or otherwise does not necessarily constitute or imply its endorsement, recommendation, or favoring by the United States government or any agency thereof. The views and opinions of authors expressed herein do not necessarily state or reflect those of the United States government or any agency thereof.

Available electronically at http://www.osti.gov/bridge

Available for a processing fee to U.S. Department of Energy and its contractors, in paper, from:

U.S. Department of Energy

Office of Scientific and Technical Information

P.O. Box 62

Oak Ridge, TN 37831-0062

phone: 865.576 .8401

fax: 865.576 .5728

email: mailto:reports@adonis.osti.gov

Available for sale to the public, in paper, from:

U.S. Department of Commerce

National Technical Information Service

5285 Port Royal Road

Springfield, VA 22161

phone: 800.553.6847

fax: 703.605.6900

email: orders@ntis.fedworld.gov

online ordering: http://www.ntis.gov/ordering.htm 


\section{Acknowledgments}

Many individuals contributed to this paper. Thanks go to the individuals from each state profiled here who assisted by detailing the characteristics and nuances of individual state tax policies. In addition, thanks go to Stephen Grover (ECONorthwest) and Charles Kubert (Clean Energy States Alliance) for their reviews of earlier versions of this report. Finally, thanks to our NREL communications editor Mike Meshek and to the Weatherization and Intergovernmental Program within the U.S. Department of Energy for funding this work. Of course, any remaining omissions or errors are the sole responsibility of the authors. 


\section{Executive Summary}

State tax incentives are a broad and flexible policy tool that can be structured to meet various state clean energy goals. Policymakers often use state tax incentives and existing state and federal policies in concert to support renewable energy deployment or reduce specific state and local market barriers. The analysis described in this report used case studies of four states to assess the contributions of state tax incentives to the development of renewable energy markets. The report also highlights important policy design considerations for policymakers.

State tax incentives that are appropriately paired with complementary state and federal policies generally provide viable mechanisms to support renewable energy deployment. ${ }^{1}$ State tax incentives offer advantages over other policy approaches in the following applications:

- States and localities with little or no existing renewable energy policy

- States or localities that wish to prioritize the development of a specific renewable energy technology

- Regions with marginally higher costs of renewable energy development

- States and localities where tax policy differs greatly from that of surrounding localities.

However, challenges to successful implementation of state tax incentives include serving project owners with limited state tax liability, assessing the appropriate incentive level, and differentiating the level of incentive for technologies with different costs. Additionally, state tax incentives may result in a moderately higher federal tax burden. ${ }^{2}$ In light of these challenges and others, a well designed state tax incentive will:

- Account for overlap and interactions with existing renewable energy policy

- Ensure the incentive term and level fit the goal of the policy

- Develop a mechanism for entities without sufficient tax liability to take advantage of the incentive

- Target specific regions and technology markets requiring incremental financial incentives.

A state tax incentive that considers these policy design characteristics can support renewable energy markets and a state's associated clean energy goals. However, the scale of impact is directly related to the degree to which the incentive supports the renewable energy market for the targeted sectors and technologies.

\footnotetext{
${ }^{1}$ Complementary policies may work in conjunction with state tax incentives to reduce technical barriers (e.g. interconnection standards or technology certification) or provide supplementary financial incentives.

${ }^{2}$ This occurs when a state tax incentive reduces the amount of deduction claimed on a federal return. In this case, the value of the state tax incentive is effectively taxed at the federal tax rate.
} 


\section{Table of Contents}

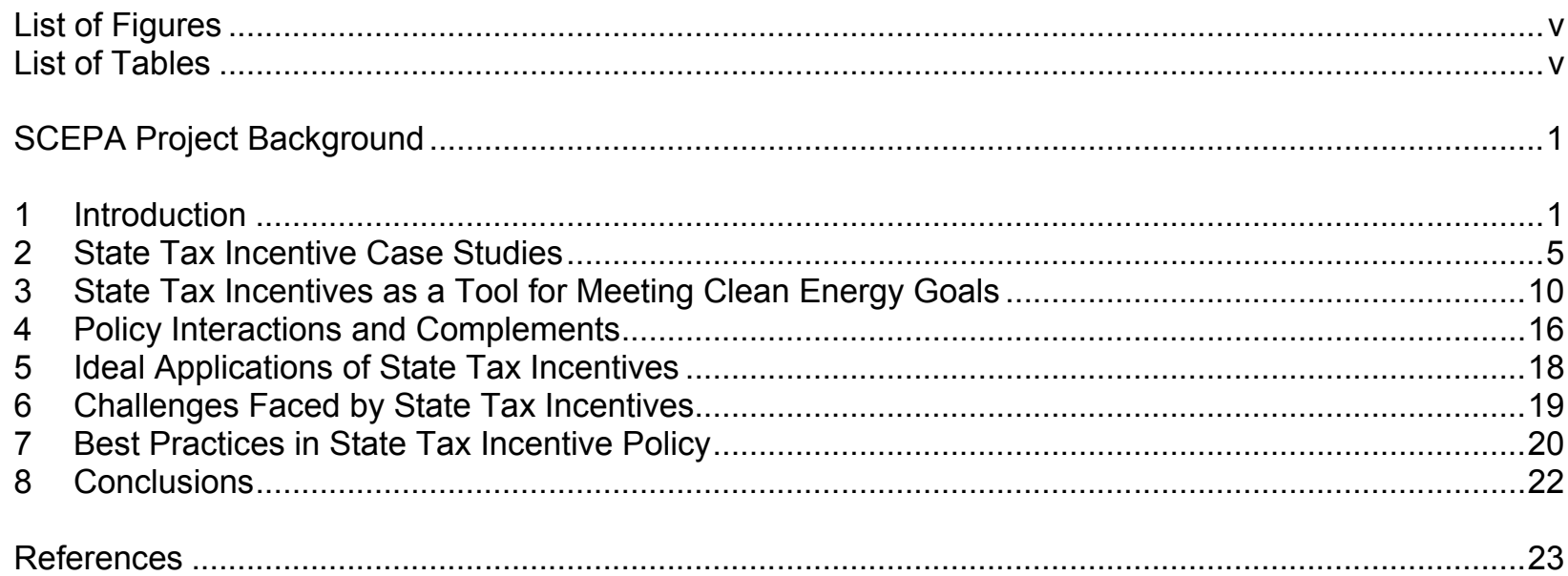

\section{List of Figures}

Figure 1. Distribution of property tax incentives by state ...................................................................

Figure 2. Distribution of corporate and personal income tax incentives by state ......................................4

\section{List of Tables}

Table 1. Renewable Energy Installations Supported by State Tax Incentives ....................................11

Table 2. Estimated Energy Production from Facilities Supported by State Tax Incentives .....................11

Table 3. Gross Economic Development Impacts from Renewables Projects Receiving Oregon's BETC

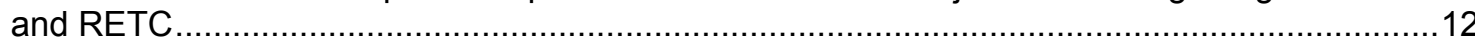

Table 4. Estimated Gross Economic Development Impacts from Wind Energy Supported by State Tax

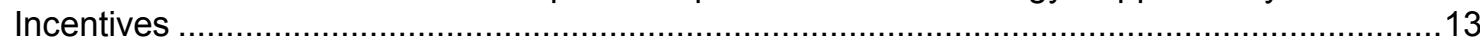

Table 5. Annual Emissions Reductions from Renewable Energy Projects Supported by State Tax Incentives

Table 6. Qualitative Impacts of State Tax Incentives on Clean Energy Policy Drivers 


\section{SCEPA Project Background}

The State Clean Energy Policies Analysis (SCEPA) project seeks to quantify the impacts of existing state policies and identify crucial policy attributes and their potential applicability to other states. The project goal is to assist states in determining which clean energy policies or policy portfolios will best accomplish their environmental, economic, and security goals. Analysts from the National Renewable Energy Laboratory (NREL) are implementing the project. State officials and policy experts are providing input and review. This report focuses on state tax incentives, which are being analyzed as part of this project. For more information on the SCEPA project or to see additional reports from the SCEPA project, access NREL's Applying Technologies Web site at http://www.nrel.gov/applying technologies/scepa.html. The SCEPA project is supported by the Weatherization and Intergovernmental Program within the Department of Energy's Office of Energy Efficiency and Renewable Energy.

\section{Introduction}

A tax incentive is designed to encourage a consumer behavior by providing a reduction in tax liability. Tax incentives have long been used to promote the adoption of emerging technologies in the energy sector. In the case of renewable energy technologies, tax incentives are designed to either reduce consumer costs or increase the value of renewable energy production, thereby increasing a project's financial feasibility. ${ }^{3}$

Tax incentives have had a remarkable impact on U.S. renewable energy markets. Most notable are the impacts of the federal production tax credit (PTC) on the utility-scale wind industry (Wiser et al.2007). However, state tax incentives like Oregon's Business Energy Tax Credit (BETC) also play an important role in renewable energy markets.

The purpose of this paper is to provide an overview of state tax incentive policies, discuss their impacts on renewable energy markets, and highlight renewable energy tax policy best practices. The first portion of the paper discusses the implications of various forms of state tax incentives. The second portion covers the prevalence of state tax incentives and uses case studies to demonstrate types of tax incentives at work. It also summarizes the impacts of state tax incentives on other high-level clean energy policy drivers, including renewable energy deployment, energy security, economic development, and the environment. The third and final portion of the analysis highlights state tax incentive program challenges, critical policy design characteristics, and ideal applications, as well as policy alternatives, complements, and interactions.

\footnotetext{
${ }^{3}$ Because tax incentives encourage financial feasibility by reducing tax liability, an important consideration in tax incentive design is whether the targeted market populations have sufficient tax liability to capture the incentive's full value. In addition, the time lag involved - from the time of the system's purchase to the time of the tax credit's monetization when the tax return is filed-requires some operating capital that may not be available to all potential consumers of renewable energy technologies.
} 


\subsection{Types of State Tax Incentives}

As a policy tool, tax incentives cover a broad range of actual financial value. They can range from sales tax exemptions on residential photovoltaic (PV) systems to utility scale production incentives worth more than $\$ 20 / \mathrm{MWh}$ on a 20 -year levelized basis (Wiser et.al. 2007). ${ }^{4}$ As such flexible policy tools, tax incentives can be applied in a variety of ways. This has likely contributed to their popularity.

Tax incentives are generally categorized as personal income tax incentives, corporate income tax incentives, sales tax incentives, and property tax incentives. Within the personal income and corporate income categories, incentives may be investment or production incentives. The former provides an incentive based on the size of the initial investment, and the latter provides an incentive based on the amount of energy produced. Tax incentives may also be applied to parties without tax liability by allowing a "passthrough" or other mechanism that permits the sale or refund of the tax credit. The remainder of this section describes each of these incentive types.

Personal income tax incentives offset personal income tax liability in the form of a tax deduction (reduction in taxable income) or tax credit (reduction in actual taxes owed). Personal income tax incentives may apply to the full array of renewable energy technologies or be limited to one specific technology. Typically, these incentives are investment-based incentives, meaning the individual can take a tax deduction or credit based on a set percentage of the cost of the system.

Corporate income tax incentives offset corporate or business tax liability and may take the form of a tax deduction or tax credit. Corporate tax incentives may be limited to renewable energy projects where the energy is produced and used on-site, or they may include utility-scale renewable energy plants whose primary purpose is to produce power for sale into wholesale energy markets. Corporate tax incentives may be investment- or production-based.

Sales Tax Incentives reduce - or provide exemptions from — sales taxes and use taxes levied against goods purchased for renewable energy projects. This type of incentive may be structured to reduce only a portion of the sales tax on a specific item, or it can provide a full sales tax exemption on an array of goods used in the construction and operation of a renewable energy project. A sales tax exemption may be applied to either distributedscale technologies or utility-scale projects. Sales tax exemptions can be designed for individuals or businesses.

Property Tax Incentives reduce or limit the amount of taxes levied against property improvements as a result of renewable energy projects. Depending on state and local property tax policy, these abatements may apply to personal or real property. Like sales tax incentives, property tax incentives may be targeted to distributed-scale applications or

\footnotetext{
${ }^{4}$ This value is commonly noted to constitute approximately $30 \%$ of the value of a utility-scale wind energy project. Because tax credits represent after-tax income, the actual value is more than $\$ 20$ per $\mathrm{MWh}$ for 20 years. Therefore, on a pre-tax income basis the actual value of the federal PTC is estimated at $\$ 30.8 / \mathrm{MWh}$ for 10 years, which equates to $\$ 20.4 / \mathrm{MWh}$ in equivalent pre-tax income levelized over 20years (Wiser et.al. 2007).
} 
utility-scale investments. Property tax incentives may be structured as a partial or full abatement.

While many states offer property tax abatements for utility-scale renewable energy projects, local governments typically receive some form of property tax reimbursement. These alternative payments may be voluntary or required by legislation. Generally, local taxing entities receive payments in lieu of tax (PILOT) for utility-scale projects. The project owner or developer and the local government at the site of the project negotiate the PILOT, which may be comparable or well below the tax as calculated under standard property tax policy.

Investment-based tax incentives are tax credits or deductions based on renewable energy system costs. Investment-based incentives can be used for either personal or corporate tax incentives. These are often applied to technologies with high initial costs, as they ultimately function to reduce the purchaser's initial investment. However, an investment tax incentive's ability to reduce investment cost is complicated by the lag time between the system's purchase and the realization of the tax credit's value when tax returns are received. As well, because investment-based tax credits are based on capital cost, they provide no direct incentive to maximize energy production. In attempts to correct this aspect of investment based incentives, some policymakers have implemented equipment or installation certification requirements. This helps to ensure that a given installation meets industry standards.

Production-based tax incentives allocate tax credits or deductions based on the units of energy generated. A production-based tax incentive may apply to either personal or corporate tax incentives. The term of a production-based tax incentive is subject to tax policy design. However, a production-based tax incentive often provides a given system with a multi-year tax benefit. Production-based credits provide a significant incentive for maximizing energy production but do not address the first-cost barriers of specific renewable energy technologies.

\subsection{Prevalence and Overview of State Tax Incentive Policies}

As of January 2009, the Database of State Incentives for Renewables and Efficiency (DSIRE) (http://www.dsireusa.org/) included more than 130 different state and local tax incentives for renewable energy. This collection of policies and descriptions represents the most comprehensive compilation of state tax incentives in the United States. Additionally, DSIRE covers all tax policy types, for all states. DSIRE data include statelevel tax incentives as well as county and local tax incentives.

According to the January data set, 45 five states have at least one state or local tax incentive targeting renewable energy technology. Property tax incentives constitute the most common policy type with 52 policies in 33 states. Corporate income tax incentives comprise the next common policy type with 32 policies in 24 states. State sales tax incentives account for 26 policies in 22 states, and personal income tax incentives are represented by 28 policies in 19 states. Figure 1 shows the distribution of property tax incentives by state. Figure 2 illustrates the distribution of corporate and personal income tax credits. Data in Figure 1 and Figure 2 are as reported by DSIRE in July of 2009. For 
additional information on specific state tax incentives or to see additional maps and information go to http://www.dsireusa.org/.

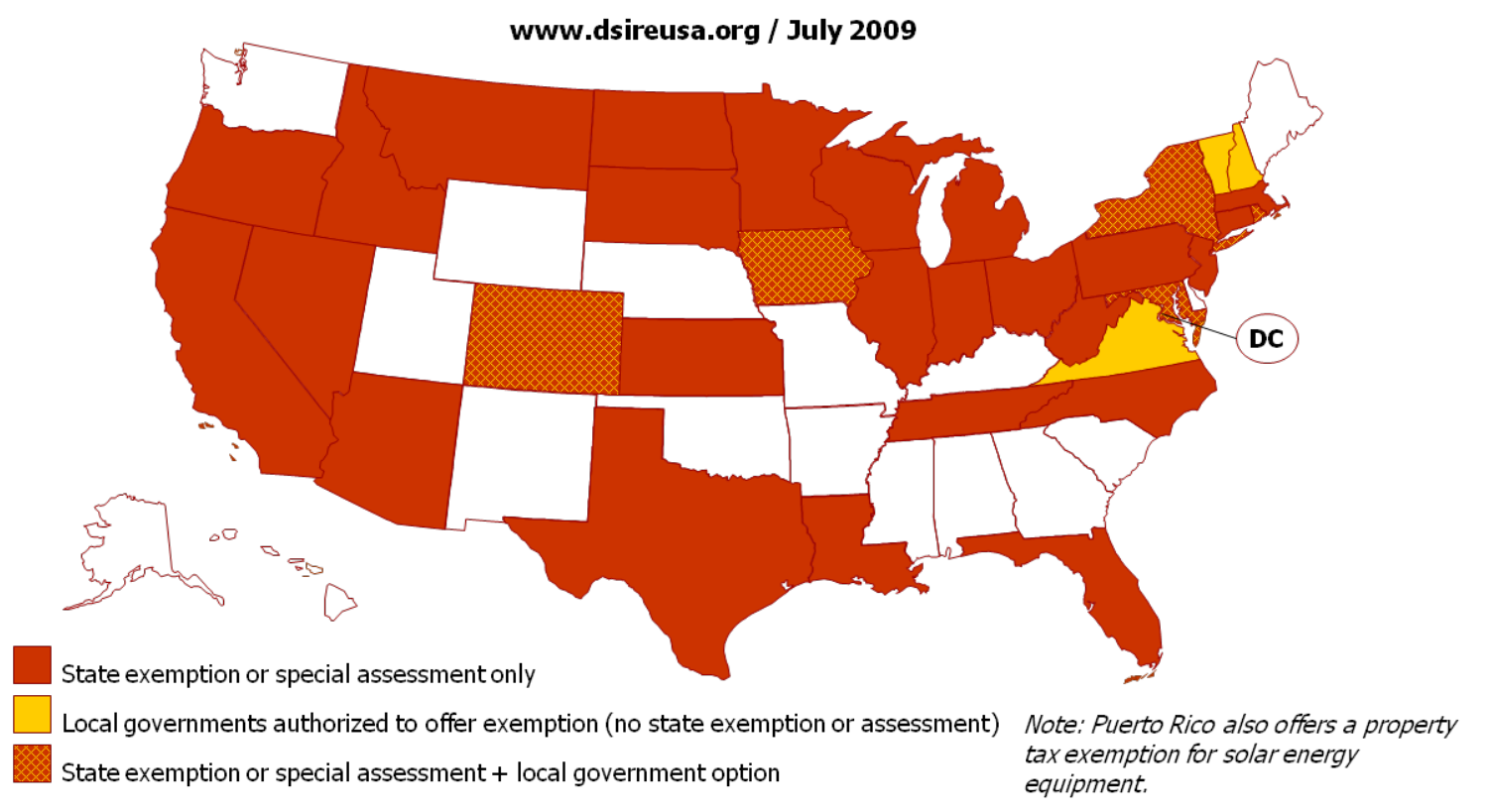

Figure 1. Distribution of property tax incentives by state

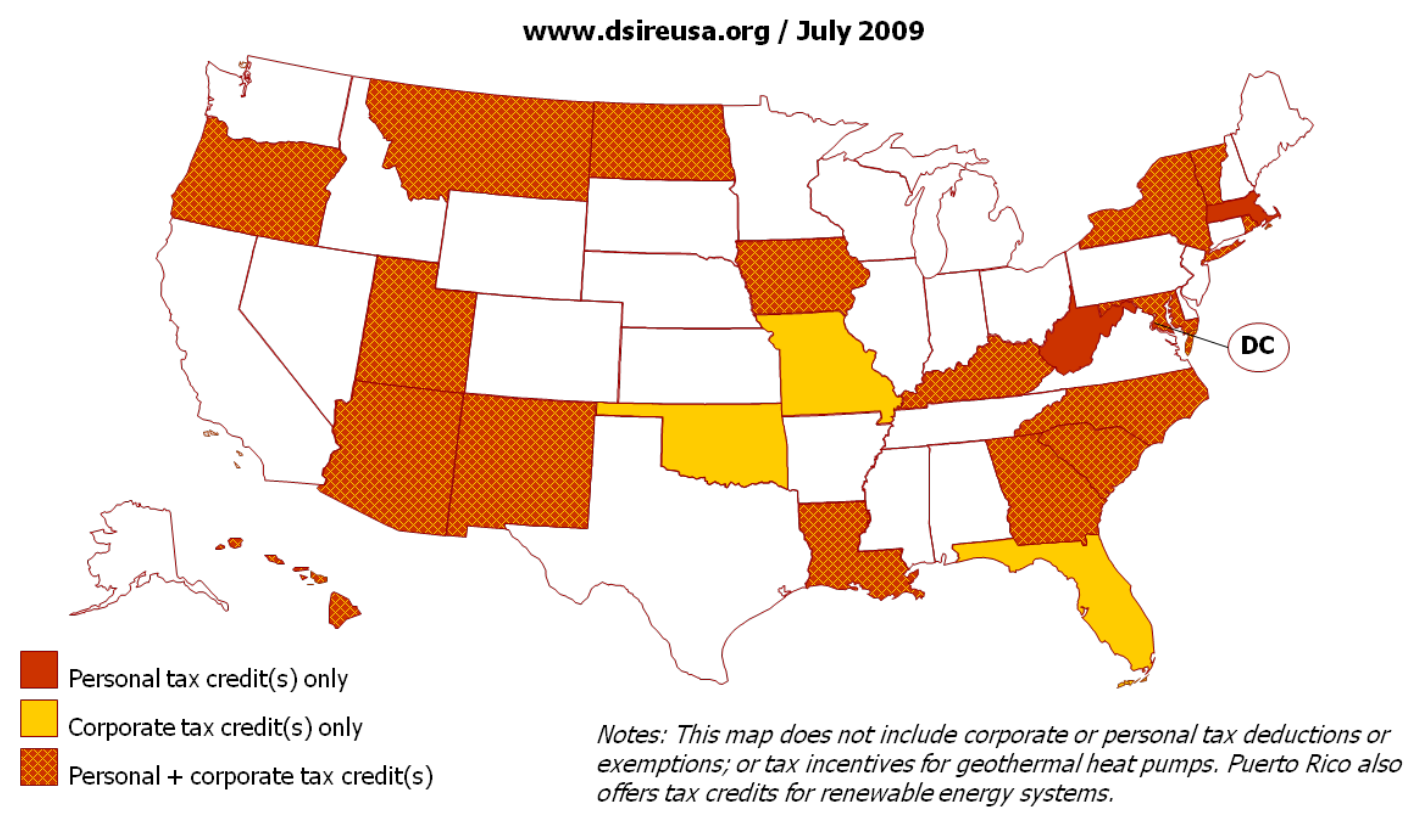

Figure 2. Distribution of corporate and personal income tax incentives by state

Many tax incentives target the whole array of renewable energy technologies, while others are limited to specific technologies or ownership structures. Specific tax incentives may limit the total capacity or number of systems that can qualify for tax incentives. Incentive amounts vary widely. On the high end, the Oregon Business Energy Tax Credit 
(BETC) provides a transferable 50\% investment tax credit to renewable energy investments (ODOE 2008). ${ }^{5}$ Alternatively Nebraska's sales and use tax exemption eliminates sales tax on goods purchased for use in a community wind energy project (Thomas 2009).

The impact on government revenue also varies widely, depending on the size of the incentive, the ability of qualifying entities to monetize the incentive (i.e. the tax appetite of qualifying individuals or business), and the number of individuals or businesses that are eligible to capture a given incentive.

To demonstrate the various forms and market impacts of state tax incentives, the following portion of this report reviews five specific, state-level incentive programs in four states.

\section{State Tax Incentive Case Studies}

Variation in state tax incentive types and applications complicate any generalizations made about impacts of these policies. The four states profiled here represent the range of tax incentive types that states may pursue, and they illustrate the strengths and weaknesses of the different tax incentive mechanisms. Though three of the state tax incentives profiled here are predominantly used by utility-scale wind energy, only one of is limited to utility-scale wind energy. In addition, renewable energy installations discussed here may also qualify for and receive the federal production tax credit (PTC) or the federal investment tax credit (ITC), as well as other state and utility renewable energy incentives.

The states profiled were chosen based on their ability to demonstrate the types of renewable energy tax incentives in use and because of the authors' familiarity with individual state tax policies and their impacts. ${ }^{6}$ In addition, incentives in three of these states have a long history and show how policies have been modified based on lessons learned and evolving priorities. The other state case study is of interest because it was designed specifically to support growth in the community wind sector. Included in each case study is an overview of each incentive, highlights from program activity, and the estimated cost of the program. ${ }^{7}$

\subsection{Oregon's Business and Residential Energy Tax Credits}

State-level tax incentives for renewable energy have been a part of public policy in Oregon since the implementation of the state's Residential Energy Tax Credit (RETC) in 1977. The state promulgated its first Business Energy Tax Credit (BETC) in 1979, and Oregon continues to be a leader in the use of state tax incentives to support clean energy (Dillard 2006).

\footnotetext{
${ }^{5}$ Transfers of this tax incentive are based on the net present value (NPV) of the tax credit paid out over 5 years; as a result, the actual real dollar transfer amount is somewhat less than $50 \%$.

${ }^{6}$ Other states likely provide feasible case studies. However, these five case studies were deemed sufficient to represent the breadth of state tax incentives.

${ }^{7}$ Estimated cost of the program may also be considered the taxpayer's cost or the tax incentive's impact on the government's general fund.
} 
The first state tax credits in Oregon applied to solar heating systems, geothermal heating systems, and wind power generation. Later, tax credits were extended to incorporate energy efficiency improvements and hybrid or alternative fuel vehicles. Furthermore, Oregon implemented the Pass-through Option in 2001. This modification allows Oregon non-profits, tribes, or other public entities, as well as individuals and businesses with little or zero Oregon tax liability to take advantage of state tax credits by transferring the tax credit to a qualifying Oregon entity, with sufficient tax appetite, for a lump sum payment (Dillard 2006). ${ }^{8}$

\section{Residential Energy Tax Credit Details}

Today the Oregon RETC is calculated based on expected energy savings. The tax credit has a maximum value of $\$ 1,500$ to $\$ 6,000$ per project, depending on the technology. ${ }^{9}$ Eligible renewable energy technologies include solar water and space heaters, solar photovoltaic systems, wind systems, fuel cells, geothermal systems, and hydroelectric systems. Residential installations can use the Pass-through Option (ODOE 2006).

The RETC program funded energy tax credits for more than 1,800 residential renewable energy installations from January 2006 through October of 2008. The cost to the state's general fund was approximately $\$ 4.7$ million. The average cost per renewable energy system is estimated to be $\$ 2,500$. The estimated net savings in energy related expenditures from these installations is $\$ 328,000$ annually (Grover et al. 2007, 2009). ${ }^{10}$

Renewable energy projects account for disproportionately large shares of total RETC costs and energy savings but make up a small proportion of the whole program. Renewable energy technologies that were installed from January 2006 through October 2008 and that received the tax credit accounted for $2 \%$ of the total RETC tax credits. Those same projects accounted for $12 \%$ of total RETC costs share and 5\% of total energy savings for the same period (Grover et al. 2007, 2009).

\section{Business Energy Tax Credit Details}

In 2006, the BETC for energy conservation and renewable energy technologies was 35\% of eligible project costs taken over five years. ${ }^{11}$ In 2007, the tax credit for renewable energy projects was increased to $50 \%$ of eligible project costs. ${ }^{12}$ Today, renewable energy technologies are eligible for the $50 \%$ tax credit while energy conservation

\footnotetext{
${ }^{8}$ The state sets the payments associated with the use of the Pass-through Option. The lump sum payment of the credit is discounted to account for payment of the tax credit over a five-year period; effectively, the transfer payment is the net present value (NPV) of the $50 \%$ tax credit paid out over five years.

${ }^{9}$ In Oregon, energy efficiency and conservation credits are worth a maximum of $\$ 1,000$ per residence per year. Hybrid and alternative fuel vehicles are eligible for up to $\$ 1,500$ per vehicle. Solar PV installations can receive a credit up to $\$ 6,000$ per system over five-year period.

${ }^{10}$ Savings in energy related expenditures are represented by the reduction in energy costs for individuals who received tax credits for renewable energy installations from January 1, 2006 through October of 2008. This savings estimate assumes average program freeridership of $20 \%$ and does not include the value to energy savings from program freeriders. This level of savings suggests that the simple payback for these systems is approximately 14 years. Of course, these savings accrue to the individuals receiving tax credits not the state's general fund.

${ }^{11}$ Ten percent of project costs were eligible for years $1-2$, and $5 \%$ project costs were eligible for years 3-5.

${ }^{12}$ A $50 \%$ tax credit is claimed at $10 \%$ per year for the full five-year period.
} 
technologies receive the $35 \%$ tax credit. The maximum credit allowed is $\$ 10$ million for renewable energy power generation projects and $\$ 20$ million for renewable energy manufacturing facilities (ODOE 2008). The cap on power generation projects limits the impact of the BETC on utility-scale renewable generation projects.

Renewable energy projects eligible for the BETC include wind, hydro, solar, geothermal, and biomass technologies. For projects that consume the energy from the system on-site, the renewable energy installation must offset $10 \%$ of the conventional energy used to operate the facility. In addition, businesses or public institutions without sufficient tax liability in Oregon may make use of the Pass-through Option described above (ODOE 2008).

From 2007 through October 2008, BETC administrators approved approximately 250 tax credits for renewable energy projects. Renewable energy tax credits for this period totaled \$136 million. On average, each project approved during this time cost the state's general fund an estimated $\$ 540,000 .{ }^{13}$ Despite the high cost of renewable energy tax credits during this period, the estimated savings from reduced expenditures for conventional energy resources is more than $\$ 195$ million annually (Grover et al. 2009). ${ }^{14}$

\subsection{Nebraska's Sales and Use Tax Exemption}

As part of a broader Community-Based Energy Development (C-BED) initiative, Nebraska promulgated and implemented the sales and use tax exemption for community wind projects in 2007. As a policy tool, C-BED encourages Nebraska-based ownership of wind projects in the state by requiring that $33 \%$ of gross project revenues flow to qualified Nebraska individuals or businesses. In addition, it reduces barriers to wind development associated with Nebraska's status as a " $100 \%$ public power" state. ${ }^{15}$

To facilitate Community-Based Energy Development, qualifying projects are allowed a sales and use tax exemption. ${ }^{16}$ As the statutes are written, qualifying C-BED projects are not subject to sales and use tax for any form of personal property used in the project (Nebraska Revenue Ruling 01-08-1). ${ }^{17}$

Sales tax in Nebraska is set at both the state and local jurisdictional levels. State sales tax is $5.5 \%$, and local tax ranges from $0.5 \%$ to $1.5 \%$, providing a total sales tax range from $6 \%$ to $7 \%$ (NE DOR 2009). The C-BED exemption applies to both state and local sales and use tax (Thomas 2009). Because investments for wind power projects are on the order of hundreds of millions of dollars, the sales tax exemption for C-BED projects is considerable. A typical wind farm may cost $\$ 2$ million per MW of installed capacity, and an $80-\mathrm{MW}, \mathrm{C}-\mathrm{BED}$ project was completed early this year. At $6 \%$ to $7 \%$ sales tax rate, the

\footnotetext{
${ }^{13}$ Estimate calculated from data published by Grover (2009)

${ }^{14}$ Again, the reduction in expenditures for conventional energy resources removes savings resulting from freerider participation. Likewise, cost savings resulting from these installations accrues to the private sector not the state's general fund.

${ }^{15}$ All electric utility companies in Nebraska are taxpayer-owned.

${ }^{16}$ To be clear, sales tax and use tax are effectively the same. Use tax is merely collected on taxable transactions that are not captured by the traditional sales tax mechanism. The consumer, not the seller, remits the use tax.

${ }^{17} \mathrm{http}: / /$ www.revenue.ne.gov/legal/rulings/rr010801.html
} 
turbines alone, for an $80 \mathrm{MW}$ facility installed at price of $\$ 1.8$ million to $\$ 2.0$ million per $\mathrm{MW}$, would result in a onetime tax reduction of $\$ 6.5-8.5$ million. $^{18}$

The project noted above is the first project to qualify for Nebraska's C-BED status. A 40 MW C-BED facility now in late-stage development is also expected to qualify as a CBED project. It will presumably qualify for this sales tax exemption as well.

Nevertheless, it is too early to tell the full impact this tax incentive will play in wind power growth in the state. Nebraska's valuable wind resource suggests that financial constraints may not be the primary barrier to development, but this incremental incentive may be important for the development of C-BED projects in the state.

\subsection{Kansas Property Tax Incentive}

In 1999, the Kansas state legislature exempted all electric generating properties that use renewable technology from paying property tax. ${ }^{19}$ However, up to this point, during the siting negotiation process all owners of completed utility-scale wind power projects in Kansas have agreed to make voluntary payments in lieu of tax (PILOT) to local taxing entities. Wind power PILOT payments in Kansas vary depending on specific negotiations between the project owner and local officials, but they typically range from $\$ 1,000 / \mathrm{MW}$ to $\$ 4,500 / \mathrm{MW} .^{20}$ The Kansas Corporation Commission (KCC) estimated them to be on the order of property tax payments in other states (Bird et.al. 2003). Subsequent research by industry (Ault 2003) and NREL suggests that Kansas PILOT are on the low end of the spectrum of property tax payments made by wind power generators around the country. ${ }^{21}$

Kansas wind power PILOT provide a point of negotiation for project developers and represent a sizable tax savings. Without the property tax exemption, a renewable energy generator would be liable for standard property tax on $33 \%$ of the depreciated value of the wind facility. ${ }^{22}$ NREL research has estimated that the 112 MW Gray County Wind Farm completed in 2001 would have been liable for more than $\$ 4.7$ million in property tax in 2002 without the property tax exemption. With it, the project owners paid $\$ 330,000$, saving nearly $\$ 4.5$ million for the project owner (Bird et al.2003). Though savings from the property tax exemption will decline in value over time, the exemption represents a notable benefit to wind project owners.

As of year-end 2008, seven utility-scale wind power projects in Kansas were generating approximately $813 \mathrm{MW}$. According to the Kansas Energy Office, each of these facilities qualifies for the property tax exemption, but all make payments to local government in the form of PILOT (Ploger 2009).

\footnotetext{
${ }^{18}$ Turbines represent approximately $75 \%$ of the total cost of wind energy projects. This estimate is based on a low $6 \%$ sales tax rate and a high $7 \%$ sales tax rate. Sales tax savings is calculated conservatively, only for the cost of the turbines themselves. In reality, materials qualifying for the exemption also include materials used in the installation of the machines and in the utility interconnection.

${ }^{19} \mathrm{http}$ ://www.kslegislature.org/legsrv-statutes/getStatuteFile.do?number=/79-201.html

20 Data compiled by the Kansas Energy Office from existing wind power plants in Kansas

${ }^{21}$ NREL's Wind Powering America Program maintains an internal database of property tax payments from wind power projects around the country.

${ }^{22}$ Property tax in Kansas is calculated based on the assessed value of the property multiplied by the local millage rate. Utility generation property is assessed at $33 \%$ of its depreciated value.
} 


\subsection{New Mexico's Renewable Energy Production Tax Credit}

New Mexico implemented a renewable energy production tax credit (PTC) for qualifying facilities in 2002. Once approved and certified, a qualifying facility receives the credit for 10 years. The standard tax credit, available to wind, solar, and biomass technologies, is $\$ 0.01 / \mathrm{kWh}$ up to $\$ 4$ million per project per year. However, there are additional credits set aside specifically for solar energy generators with an average value of $\$ 0.027 / \mathrm{kWh}$ up to $\$ 5.4$ million per year. ${ }^{23}$ The total state allowance for tax credits is 2.5 million MWh; two million MWh are available to wind, solar, and biomass generators while an additional $500,000 \mathrm{MWh}$ of tax credit are set aside specifically for solar power generators (DSIRE 2009).

According to the legislation, entities filing personal or corporate tax returns are eligible for the tax credit for projects that generate at least $1 \mathrm{MW}$. Projects that were generating power prior to October 1, 2007 can carry forward excess tax credit for five years. Excess tax credits are refunded to taxpayers for projects that began generating power on or after October 1, 2007. Therefore, monetizing the incentive's value for facilities built after October 1, 2007 is a straightforward process even when project owners have limited tax appetite.

New Mexico's PTC was first passed in 2002 and amended in 2003 and 2007. In the original bill, wind generators were the sole eligible resource. Solar PV systems, solar thermal electricity generators, and biomass generators were added with the amendments in 2003. The 2007 amendment gave solar power generators a tax credit "set aside" of $500,000 \mathrm{MWh}$ that is slated to remain in place through 2018.

According to the New Mexico Energy, Minerals, and Natural Resources Department, the PTC was successful in stimulating increased interest in developing the state's renewable energy resources (McDiarmid 2009). Allocations for the cross-technology PTC are fully subscribed. Four wind projects and one $30 \mathrm{MW}$ biomass facility are in operation. Two additional wind power plants are approved to receive the tax credit once construction is completed. When all approved projects are completed the total expected capacity supported by the multi-resource, standard, PTC is 734 MW (McDiarmid 2009).

Under the NM PTC interest in building solar power projects has grown and a few smaller projects are expected to begin construction possibly in late 2009 or early 2010. However, at the time of this research no solar projects have yet received preliminary approval for the tax credits (McDiarmid 2009). ${ }^{24}$

At current levels, the PTC costs New Mexico an estimated \$12 million annually. When all approved projects are on line, the cost to the state's general fund is expected to be $\$ 20$

\footnotetext{
${ }^{23}$ The solar energy tax credits are variable over the life of the facility. The value noted here reflects the average annual value of the tax credit.

${ }^{24}$ Under the New Mexico PTC, an individual or business may apply for the tax credit before beginning construction on projects. To be approved, a project must have a detailed timeline in place for construction and operation of the facility. Once a project has been approved, the amount of tax credits the generator expects to receive is reserved for that project. To maintain rights to the tax credits, generators must be producing electricity within 24 months of the approval date.
} 
million. Once the solar set aside is fully subscribed, the average annual cost of the total program will be $\$ 33.5$ million. $^{25}$

\subsection{Case Study Summary}

Interest in and uptake of state tax incentives is high, regardless of the type of incentive or its value. However, this does not clearly indicate that state tax incentives are driving renewable energy deployment. Most state tax incentives exist within a broader array of state incentives and regulations, including renewable energy rebates, renewable portfolio standards, loan and financing programs, and net metering laws. Federal policy incentives, including the federal production tax credit (PTC) and the investment tax credit (ITC), also play an important role in renewable energy market development. As a result, parsing the direct impact of a specific tax incentive remains difficult.

The following portion of this analysis attempts to assess the value of tax incentives in regards to specific high-level renewable energy policy goals.

\section{State Tax Incentives as a Tool for Meeting Clean Energy Goals}

A critical piece of the SCEPA project is evaluating the abilities of state policies to effect clean energy goals, including reduced environmental impact, enhanced economic development, increased energy security, and/or rapid renewable energy deployment. To assess the capability of state tax incentives to serve high-level state energy goals, the case studies are evaluated for their impacts on the goals noted above.

The capacity of tax incentives to impact clean energy goals is first measured quantitatively by evaluating the impacts of all projects that use state tax incentives. The basic assumption in this portion of the analysis is that these projects are unlikely to be built without the state tax incentives. ${ }^{26}$ The quantitative analysis is supplemented with a qualitative assessment that accounts, to a degree, for the fact that state tax incentives exist alongside other state and federal policies that also support these projects. In brief, the qualitative assessment summarizes how tax incentives are expected to impact directly the four clean energy policy goals outlined above. It also highlights the market conditions where well designed tax incentives are likely to have a greater impact.

\subsection{Quantitative Analysis}

At the basic level, clean energy policy is intended to increase the application and use of clean energy technologies. Here, the impact of renewable energy tax incentives on deployment of renewable energy technologies is considered. Table 1 summarizes the extent of renewable energy deployment in each state studied above.

\footnotetext{
${ }^{25}$ The term average cost is used here because individual years may vary as a result of the variable nature of the solar power PTC.

${ }^{26}$ This assumption may be a matter for debate. However, the intent here is not to determine the actual project-by-project value of the specific tax incentive but to evaluate the impacts of projects that receive support from state tax incentives.
} 
Table 1. Renewable Energy Installations Supported by State Tax Incentives

\begin{tabular}{lcc}
\hline $\begin{array}{l}\text { Data Reported by Installed Capacity } \\
\text { (Utility-scale) }\end{array}$ & Years of Data & Installations \\
\cline { 2 - 3 } Kansas & 9 & $813 \mathrm{MW}^{*}$ \\
Nebraska & 1.5 & $120 \mathrm{MW}^{*}$ \\
New Mexico & 6 & $734 \mathrm{MW}^{\star}$ \\
\hline Data Reported by Systems Installed & \multicolumn{2}{c}{} \\
(Residential, Commercial, and Utility-scale) & Years of Data & Installations \\
Oregon BETC & $3^{* *}$ & 298 systems \\
Oregon RETC & $2.8^{* \star *}$ & 1848 systems \\
\hline
\end{tabular}

* Includes capacity expected to come online in 2009

** Includes projects installed from 2006 through 2008 (Merrill 2009)

*** Includes projects installed from 2006 through October 2008 (Grover 2009).

Sources: Kansas Corporation Commission, New Mexico Department of Energy, Minerals, and Natural Resources, Nebraska Wind Working Group, Oregon Department of Energy.

\section{Impacts on Energy Security}

To the extent that state tax incentives increase renewable energy production, they reduce consumption of finite fossil resources. ${ }^{27}$ Table 2 highlights estimated annual energy production from renewable energy facilities supported by state tax incentives in Kansas, New Mexico, and Nebraska. Energy production values for Nebraska and New Mexico include capacity expected to come online in 2009.

Table 2. Estimated Energy Production from Facilities Supported by State Tax Incentives

\begin{tabular}{ccc}
\hline State & $\begin{array}{c}\text { Estimated Production } \\
\text { (MWh) }\end{array}$ & $\begin{array}{c}\text { Percentage of State } \\
\text { Electricity Retail Sales }\end{array}$ \\
\cline { 2 - 3 } Kansas & $2,780,435$ & $6.9 \%$ \\
Nebraska & 428,890 & $1.5 \%$ \\
New Mexico & $2,361,871$ & $10.5 \%$ \\
\hline
\end{tabular}

Source: Estimated production is calculated from average region capacity factors. Percent of state electricity is based on total 2007 retail sales as reported by U.S. Energy Information Administration.

Table 2 shows that installations supported by state tax incentives in Kansas, New Mexico, and Nebraska are contributing to their respective energy sectors. Tax credits in Oregon also result in conventional energy resources saved..$^{28}$ In that state, renewable energy installations that received BETC and RETC tax credits from 2007 through October 2008 saved an estimated \$200 million annually in energy expenditures (Grover 2009).

However, state tax incentives do little to reduce U.S. consumption of foreign oil because the renewable energy resources supported by them are largely electricity-producing technologies. Because oil consumption is the greatest threat to U.S. energy security, tax

\footnotetext{
${ }^{27}$ In Oregon, a large portion of conventional electricity resources is hydroelectric. Thus, some energy savings constituted by the BETC and RETC programs are savings of hydroelectricity rather than power generated by fossil fuels.

${ }^{28}$ See footnote 27
} 
incentives emphasizing technologies that directly reduce consumption of imported oil are likely to contribute more to a secure energy future.

\section{Impacts on Economic Development}

Renewable energy projects and the large investments they often require can lead to opportunities to stimulate economic development. In addition, the dispersed nature and localized fuel supply of renewable energy technologies means that these economic development opportunities may have positive impacts in rural areas.

ECONorthwest has performed comprehensive analysis of economic development impacts from state tax incentives, including two detailed studies of the impacts resulting from Oregon's BETC and RETC programs (Grover 2007, 2009). ECONorthwest data presented in this report are from 2007 and 2008. These data represent only renewables development (Table 3). ${ }^{29}$ Furthermore, economic impacts reported here are gross impacts from renewables development. Thus, these data are not a measure of overall investment efficiency (i.e. job creation or economic impacts relative to other potential investment opportunities) but simply a measure of the impacts resulting from this specific investment. $^{30}$

Table 3. Gross Economic Development Impacts from Renewables Projects Receiving Oregon's BETC and RETC

\begin{tabular}{lcccc}
\hline Year & Jobs & $\begin{array}{c}\text { Wages } \\
\text { (\$ in millions) }\end{array}$ & $\begin{array}{c}\text { Tax Revenue } \\
\text { (\$ in millions) }\end{array}$ & $\begin{array}{c}\text { Output } \\
\text { (\$ in millions) }\end{array}$ \\
\cline { 2 - 5 } 2007 & 981 & 39.0 & 3.8 & 134.9 \\
2008 & 2,986 & 124.1 & 20.4 & 467.4 \\
\hline
\end{tabular}

Source: ECONorthwest (2009)

Using NREL's Job and Economic Development Impact (JEDI) model for wind, NREL analyzed the gross economic development impacts from wind energy projects supported by tax incentives in New Mexico, Kansas, and Nebraska. ${ }^{31,32}$ Table 4 shows the results of this analysis separated into short-term (single-year) construction period impacts and longterm (20-year) annual operations period impacts. ${ }^{33}$

\footnotetext{
${ }^{29}$ Renewables development from 2007 and 2008 represents a small fraction of total program activity during this period.

${ }^{30}$ ECONorthwest's original work in this area also reports net impacts. By comparing the economic development impacts resulting from BETC and RETC program expenditures with traditional government spending patterns, Grover $(2007,2009)$ finds that net economic impacts from the BETC and RETC program are positive.

${ }^{31}$ For more information on the JEDI Wind Model see http://www.nrel.gov/analysis/jedi/about_jedi_wind.html

32 The results shown here are intended to approximate the economic development impacts to each state from wind development supported by state tax incentives. Results are based on nationwide average industry costs and other model defaults. As such, the results do not indicate actual impacts. Instead, they represent the scale of impacts expected from the level of development noted in Table 1, assuming these projects reflect broader industry averages.

${ }^{33}$ Operations period earnings and output impacts are annual values. These impacts accrue for each year of operation. Operations period jobs are constant and remain at the level noted in the table for the life of the facility.
} 
Table 4. Estimated Gross Economic Development Impacts from Wind Energy Supported by State Tax Incentives

\begin{tabular}{clrcc}
\hline & & $\begin{array}{c}\text { Earnings (2009 } \\
\text { Dollars in } \\
\text { Millions) }\end{array}$ & $\begin{array}{c}\text { Output (2009 } \\
\text { Dollars In } \\
\text { Millions) }\end{array}$ \\
\cline { 3 - 5 } Kansas & Construction Period Impacts & 3,730 & $\$ 135$ & $\$ 393$ \\
(813 MW) & Annual Operations Impacts & 165 & $\$ 6.9$ & $\$ 19$ \\
Nebraska & Construction Period Impacts & 790 & $\$ 29$ & $\$ 81$ \\
(120 MW) & Annual Operations Impacts & 27 & $\$ 1.1$ & $\$ 3.2$ \\
New Mexico & Construction Period Impacts & 3,160 & $\$ 115$ & $\$ 321$ \\
(734 MW) & Annual Operations Impacts & 209 & $\$ 7.9$ & $\$ 27$ \\
\hline
\end{tabular}

Table 3 and Table 4 show that economic development is supported by renewable energy development. To the extent that state tax incentives support this development, a portion of these economic development impacts can be attributed to state tax incentives.

\section{Impacts on the Environment}

State tax incentives that support renewable energy development also have a positive impact on the environment. This portion of the analysis evaluates the impacts on air quality and greenhouse gas emissions of renewable energy development that has benefited from state tax incentives. Table 5 summarizes these results. As is the case with respect to economic development impacts, it is only to the extent that state tax incentives are a driver of this development that the environmental impacts of this development can be attributed to state tax incentives.

Table 5. Annual Emissions Reductions from Renewable Energy Projects Supported by State Tax Incentives

\begin{tabular}{lcrrr}
\hline & Units & Kansas & New Mexico & Nebraska \\
\cline { 2 - 5 } Greenhouse Gas Emissions & & & & \\
(CO equivalents) $_{\text {Nitrogen Oxides }}$ & tons & $2,210,757$ & $1,877,952$ & 341,015 \\
Sulfur Dioxide & tons & 3,075 & 2,612 & 474 \\
Mercury & tons & 8,527 & 7,243 & 1,315 \\
\hline
\end{tabular}

Source: Emissions reductions are calculated from state specific non-baseload emissions rates as reported by eGRID $20071.1^{34}$

\subsection{Qualitative Analysis}

The quantitative results from the previous section indicate that state tax incentives can support state clean energy goals. However, state tax incentives are not the sole driver behind the impacts noted above. Many of these projects also rely on other state and federal incentives. Table 6 seeks to supplement the quantitative data shown in the

\footnotetext{
${ }^{34}$ Because of their low market penetration and variable output levels, renewable energy generators typically do not offset baseload generators. Instead, renewable energy offsets generators that are on the margin. One approximation of the emissions rate of generators on the margin is the average non-baseload emissions rate. Use of the non-baseload emissions rate rather than an overall average emissions rate generally leads to more accurate estimates. However, a more detailed analysis would evaluate the actual change in generators at the margin when renewable energy comes on line rather than just apply the average non-baseload emissions rate.
} 
previous section, which are based on projects supported by state tax incentives, with a qualitative assessment of tax incentives' role within the context of other state and federal renewable energy incentives. The purpose is to highlight where state tax incentives will likely have the greatest impact in moving states towards their clean energy goals.

Qualitative evaluation is based on the authors' understanding of the specific, direct impacts of state tax incentives relative to the impacts of other state and federal policy incentives for renewable energy. 
Table 6. Qualitative Impacts of State Tax Incentives on Clean Energy Policy Drivers

\begin{tabular}{|c|c|c|c|}
\hline $\begin{array}{l}\text { Overarching } \\
\text { Renewable } \\
\text { Energy Driver }\end{array}$ & Potential Policy Goal & $\begin{array}{l}\text { Ability of state tax } \\
\text { incentives to } \\
\text { impact policy } \\
\text { goals }\end{array}$ & Discussion \\
\hline Environment & $\begin{array}{l}\text { Improved air quality }\left(\mathrm{SO}_{x}, \mathrm{NO}_{x},\right. \\
\text { Mercury, particulates) } \\
\text { Reduced greenhouse }(\mathrm{GHG}) \text { emissions } \\
\text { Reduced water consumption } \\
\text { Reduced water pollution (heat and } \\
\text { mercury) } \\
\text { Reduced fuel extraction impacts } \\
\text { Preserved sensitive areas } \\
\text { Protected wildlife/ endangered species } \\
\text { Minimized human impacts } \\
\text { Managed waste stream (farm, forestry, } \\
\text { municipal wastes) }\end{array}$ & $\begin{array}{l}\text { Limited/ } \\
\text { Moderate }\end{array}$ & $\begin{array}{l}\text { State tax incentives are typically } \\
\text { supplementary policies meant to moderately } \\
\text { enhance incentives for the development of } \\
\text { renewable energy technologies. As such, state } \\
\text { tax incentives are often limited in their ability to } \\
\text { directly support environmental goals even } \\
\text { though renewable energy is clean energy. } \\
\text { However, policymakers who design tax } \\
\text { policies to be primary drivers of renewable } \\
\text { energy markets can moderately or even } \\
\text { significantly impact environmental policy } \\
\text { goals. }\end{array}$ \\
\hline & $\begin{array}{l}\text { Minimized electricity costs } \\
\text { Minimized ratepayer impacts }\end{array}$ & Limited & Tax incentives that do not account for project \\
\hline $\begin{array}{c}\text { Economic } \\
\text { Development }\end{array}$ & $\begin{array}{l}\text { Revitalization of rural areas } \\
\text { Development of local or community- } \\
\text { owned assets } \\
\text { Job creation } \\
\text { State economic development } \\
\text { Electricity price stabilization } \\
\text { Attraction of new investment }\end{array}$ & Moderate & $\begin{array}{l}\text { margins may not provide be the most efficient } \\
\text { renewable energy policy for minimizing } \\
\text { electricity costs. Nevertheless, tax incentives } \\
\text { that either eliminate specific market barriers or } \\
\text { are designed as primary market drivers can } \\
\text { contribute to new renewable energy capacity, } \\
\text { which produces economic development } \\
\text { impacts. }\end{array}$ \\
\hline \multirow{3}{*}{ Energy Security } & $\begin{array}{l}\text { Resilient Grid System } \\
\text { Reduce transfer of wealth outside the } \\
\text { U.S. } \\
\text { Peak Demand Reduction }\end{array}$ & Limited & \multirow{3}{*}{$\begin{array}{l}\text { Tax incentives are not generally designed to } \\
\text { reduce peak demand or balance the grid } \\
\text { system. In addition, they have limited impact } \\
\text { on wealth transfer outside the country } \\
\text { because they have little impact on oil } \\
\text { consumption. However, if tax incentives are } \\
\text { designed as a primary market driver and } \\
\text { stimulate significant new renewable energy } \\
\text { capacity they can aid in the development of an } \\
\text { abundant and affordable energy supply. }\end{array}$} \\
\hline & $\begin{array}{l}\text { Encourage distributed energy } \\
\text { generation } \\
\text { Abundant energy supply } \\
\text { Affordable energy supply } \\
\text { Become a net exporter of energy }\end{array}$ & $\begin{array}{l}\text { Limited/ } \\
\text { Moderate }\end{array}$ & \\
\hline & Diversify energy resources & Moderate/High & \\
\hline $\begin{array}{l}\text { Renewable } \\
\text { Energy (RE) } \\
\text { Deployment }\end{array}$ & $\begin{array}{l}\text { Reduction of fossil fuel consumption } \\
\text { Stimulation of innovation } \\
\text { Reduction of baseload needs } \\
\text { Reduction of technical and policy } \\
\text { barriers } \\
\text { Rapid RE market } \\
\text { expansion/development } \\
\text { Basic technological advancement } \\
\text { Cost reductions at scale } \\
\text { Learning-by-doing advances } \\
\text { Compliance with Renewable Portfolio } \\
\text { Standard (RPS) quotas/targets } \\
\text { Stimulation of early adoption }\end{array}$ & $\begin{array}{l}\text { Moderate/ } \\
\text { High }\end{array}$ & $\begin{array}{l}\text { In most cases, clean energy policy is designed } \\
\text { to stimulate the expansion of renewable } \\
\text { energy markets. A well-designed tax incentive } \\
\text { can support large-scale deployment of } \\
\text { renewable energy technologies. }\end{array}$ \\
\hline
\end{tabular}


Table 6 demonstrates that tax incentives can have a wide-ranging impact depending on specific policy goals. The primary strengths of tax incentives as an overarching renewable energy driver are found in renewable energy deployment. To the extent that tax incentives support deployment, they can increase energy resource diversity and stimulate economic development. Likewise, the environment can benefit from state tax incentives that are effective in deploying large amounts of renewable energy. However, state tax incentives have not generally been designed to dramatically increase renewable energy deployment. As a result, their independent impact on high-level state energy goals is modest.

\section{Policy Interactions and Complements}

State tax incentives have generally provided an incremental incentive that supports but does not drive renewable energy growth. ${ }^{35}$ State tax incentives are most effective when implemented as a part of comprehensive package of clean energy policies and designed to address specific state or local market barriers. Thus, knowing how state tax policies interact with other state or federal incentives is critical to understanding the attributes of state tax incentives.

This portion of the paper reviews the interaction of state tax incentives and other popular renewable energy incentives. In addition, it considers potential complementary policies that, in conjunction with state tax incentives, may support growth of renewable energy capacity.

\subsection{State and Federal Tax Incentives}

The interaction of state and federal policy incentives is often fraught with ambiguity. This is especially true because states and the federal government regularly modify and amend specific incentives as well as rules and regulations. However, renewable energy project owners cannot understand the value of specific state incentives without first understanding how they interact with given federal incentives. In some cases, state incentives complement federal policy while in others they trigger double-dipping provisions. ${ }^{36}$ In all specific cases, individuals and businesses should consult with appropriate tax advisors.

IRS Revenue Ruling 2006-9 clarified one area of ambiguity in the interaction of state and federal tax incentives. ${ }^{37}$ In this ruling, state tax incentives were deemed not to trigger double-dipping provisions in the legislation of the federal production tax credit. As a result, state tax credits do not reduce the value of the federal production tax credit. ${ }^{38}$ In

\footnotetext{
${ }^{35}$ Cited historical drivers of renewable energy development in the United States often include the federal production and investment tax credits, state renewable portfolio standards, and state or utility rebate programs.

${ }^{36}$ A double-dipping provision prevents an individual or business from claiming two different incentives on the same purchase. In some cases, the individual or business is forced to choose between the two incentives, while in other cases a double-dipping provision simply reduces the level of expenditures that a tax incentive can be claimed against, which in turn reduces the value of one or both tax incentives.

${ }^{37} \mathrm{http}: / / \mathrm{www} . \mathrm{irs} . \mathrm{gov} / \mathrm{irb} / 2006-09$ IRB/ar06.html

${ }^{38}$ This was an important ruling because the language of the federal PTC states the credit is to be reduced as a result of "Grants, Tax-exempt Bonds, Subsidized Energy Financing, and Other Credits..." However,
} 
contrast to the language of the production tax credit, the legislative language of the federal investment tax credit is fairly clear in that other tax credits are not considered potential triggers of double-dipping provisions. ${ }^{39}$ Thus, state tax incentives may be a viable mechanism for reducing specific local barriers to renewable energy development while federal tax incentives increase the economic feasibility of renewable energy technologies.

\subsection{State Tax Incentives and State Rebate Programs}

While existing federal tax policy allows state tax incentives to complement federal tax incentives, the relationship between state tax incentives and state rebate programs may be more complicated. In Oregon, for example, state tax credits can be combined with utility renewable energy rebates, and individuals and businesses need not deduct the utility rebate from eligible costs considered for the tax credit (ODOE 2006). In this form, state tax incentives fully complement other utility rebate programs. ${ }^{40}$ However, depending on the specific legislation for a state tax incentive or rebate program, explicit double-dipping provisions may require individuals to choose between the state tax incentive and rebate. Historically, this approach has been taken at the federal level when two federal incentives are available at the same time.

Policymakers considering implementing a state tax incentive in conjunction with state or utility rebate programs need to consider whether they would like these policies to be complementary. In some respects, if either policy alternative is designed well, both a rebate and tax incentive may not be needed. In other cases, allowing utility or state rebates to supplement a tax incentive might be appropriate. If rebates and tax incentives are not intended to be complementary, the legislation should make clear that individuals and businesses should choose the incentives that best fit their needs. Individuals or businesses looking to install a renewable energy technology should seek appropriate counsel about their eligibility for rebates or tax incentives, as specific cases are context sensitive.

\subsection{Tax Incentives and Renewable Portfolio Standards}

Interaction of tax incentives with renewable portfolio standards (RPS) is context sensitive. ${ }^{41}$ One might argue that a well designed RPS can function as a standalone policy. However, policymaking is often an ad hoc process in which items may be added

ruling 2006-9 found that the reference to "other credits" applies only to other federal credits. If New Mexico's tax credits had triggered the double-dipping provisions of the PTC, $37 \%$ of the state PTC would have been lost as a result of the respective reduction in the federal PTC while the value of sales tax exemptions and property tax incentives would have been reduced by $15-35 \%$ (Wiser and Bolinger 2002).

${ }^{39}$ However, payments on state income taxes can be a deduction on federal tax payments. Therefore, the a state tax incentive reduces this deduction and the actual value of a corporate or personal state tax incentive is effectively subject to federal tax at the individual's or business' federal tax rate. For this reason, state tax incentives and federal tax incentives cannot be directly added.

${ }^{40}$ However, using the Pass-through Option, which provides lump sum payment to the system owner for the transfer of the tax credits to a third party, may have tax implications. ODOE recommends consulting with the appropriate tax counsel to understand the implications of using the Pass-through Option in Oregon.

${ }^{41}$ An RPS is a quota or mandate for utilities within a state to obtain a given percentage of their electricity from renewable energy resources. 
or modified to gain political support or account for weaknesses in prior legislation. Under these conditions, a tax incentive can complement an RPS.

For example, states having difficulty meeting RPS requirements may need additional incentives to jump-start renewables development or encourage a wider array of bidders. As a result, a state tax incentive in the form of a PTC or ITC may attract potential renewable energy developers and enhance a state's ability to meet its RPS. However, state tax incentives that complement renewable portfolio standards transfer costs from utility ratepayers to the tax base.

\subsection{Tax Incentives and Barrier Reduction Policies (Time of use rates, Interconnection Standards, Net-metering)}

As a policy mechanism, tax incentives enhance the financial feasibility of renewable energy projects and reduce cost barriers. However, cost barriers are not the only barrier to expanding renewable energy markets, and other policies are critical complements to state tax incentives. Technical and market structure policies that involve net-metering, interconnection standards, or time-of-use rates, for example, can simplify renewable energy development. Such policies also allow on-site consumers of power from renewable energy installations to extract increased value from their investments.

\subsection{Tax Incentives and Feed-in Tariffs}

The feed-in tariff (FIT), a recent clean energy policy alternative in North America, provides a guaranteed price for electricity generated from renewable energy resources. A FIT price may be designed based on the cost of production, or it may be structured to provide a fixed premium amount above the market price for conventional electricity generation.

From a policy design perspective, these policies are not complementary. Both policies target cost or financing barriers. Ideally, FITs are a standalone policy designed to provide sufficient incentive to encourage renewable energy deployment. The cleanest policy solution is to implement either a FIT or a tax incentive with the value of the preferred policy tool set at the level required to achieve the desired growth rate. However, additional incentives may be appropriate in individual cases where either context-specific barriers or priorities for specific ownership structures exist. In these cases, state tax incentives and FITs may be important complementary policies.

\section{Ideal Applications of State Tax Incentives}

In their role as an incremental policy support or complement, state tax incentives offer advantages over alternative policy approaches in four primary areas.

States or localities with limited existing renewable energy policy: Tax credits are widely understood, and using a state tax incentive to support renewable energy development is relatively simple. This constitutes a significant advantage over other approaches. Likewise, because they do not require specific appropriation of funds, they tend to be less politically contentious. Moreover, a tax incentive can be easily capped and therefore limit fiscal impacts. It can also be structured to target an individual technology 
or an array of technologies. The flexibility and simplicity of state tax incentives makes them ideal for localities where renewable energy policy is new or controversial.

States or localities that wish to prioritize a renewable energy technology that is not competitive under existing policy: A state or locality may have a very good renewable resource that requires a moderate additional incentive to jump-start development, perhaps because a given technology is less mature. A prime example is the solar power PTC in New Mexico. New Mexico's solar resource is among the best in the nation, but few larger-scale solar power installations have moved forward because of the cost of the technology. To encourage solar power development, New Mexico began providing the solar-specific state PTC in addition to the available federal tax credits. As a result, interest in developing solar resources has grown, and the state expects multiple projects to move forward.

Regions with moderately higher costs of renewable energy project development: In locations where development costs for mature renewable energy technologies are moderately higher than in neighboring regions, policymakers may require incremental incentives to encourage development. Moderately higher costs might arise from higher labor rates, higher property values, or variability in local renewable energy resources. The additional benefit that can be derived from a state tax incentive - such as a sales tax exemption or property tax abatement - may be enough to attract developers to a given region.

Localities with significant asymmetries in tax policy: Tax policy may not be the primary driver in the siting of renewable energy projects. However, when all other factors are comparable, a significant disparity in tax burden will likely discourage the siting of renewable energy projects in areas with higher tax burdens. For example, Kansas enacted a state property tax exemption to remain competitive with surrounding states with comparable wind resources but lower traditional property tax rates for the electric industry.

\section{Challenges Faced by State Tax Incentives}

Tax policy is limited as a tool for incentivizing renewable energy development. Designing an effective policy is complicated by differing goals among states and other context-specific considerations. This section highlights a few specific challenges of state tax incentives.

Determining the proper incentive level may be difficult because markets for renewable energy are context-sensitive and evolve over time. However, determining the proper incentive level is one of the more critical elements of a successful incentive program.

Achieving technology diversity is difficult when tax incentives are not differentiated by technology. A broad, non-differentiated tax incentive is likely to benefit only the technology that is most profitable under a given set of market and policy conditions. ${ }^{42}$

\footnotetext{
42 This may not be a problem if the desired goal is maximum renewable energy deployment.
} 
Policymakers who desire increased technological diversity must differentiate policy incentives to meet the needs of the full array of targeted technologies or resources. Such differentiation of incentives by technology requires increased market analysis and places a greater burden on policymakers and administrators.

Insufficient tax liability significantly limits use of tax policy as incentive for emerging industries. Many individuals or business may not have sufficient state tax liability to capture the full value of the credit. Furthermore, public sector and other non-taxable entities cannot use tax based incentives. ${ }^{43}$

State tax incentives are not a direct cash payment and therefore may not reduce lender risk. State tax incentives do not generally have cash value. As a result, the value of these incentives cannot serve to meet the cash-flow requirements needed to achieve the lowest level lending rates (Wiser and Rader 1999). In contrast, a direct cash subsidy that could be used to service debt may reduce investor risk and the cost of capital.

State tax incentives increase the federal tax burden. State tax payments are sometimes claimed as a deduction on federal taxes. However, a state income tax incentive reduces the amount of deduction allowed. Effectively, the value of the state income tax incentive is "taxed" at the federal tax rate, reducing its overall value to the consumer.

Tax incentives are funded by taxpayers rather than utility ratepayers. With many states struggling to meet their budgetary obligations, tax incentives represent another demand on states' general funds. In addition, critics argue that energy users should pay for new energy development. That said, evidence from the BETC and RETC tax incentive programs indicates that tax incentives directed towards renewable energy projects generate greater economic impacts than traditional government expenditures (Grover 2007, 2009).

\section{Best Practices in State Tax Incentive Policy}

The assessment provided in this report indicates that state tax incentives can be designed to serve a variety of contexts and goals. However, as applied today, these incentives mostly support existing state and federal renewable energy policy as an incremental incentive. Given this context, this section highlights critical components of policy design as it relates to renewable energy.

Understand the interactions a new tax incentive will have on other incentives. All policies interact with one another. The question is if they do so positively or negatively. When designing a new policy, one must consider how the credit may interact with existing state and federal energy policies. Is an additional tax incentive supporting or supplementing existing policies favored? Or, does the policymaker prefer to have individuals or business choosing between the tax incentive and other potential policies? The answer to these questions likely varies depending on the existing policy and its

\footnotetext{
${ }^{43}$ There are exceptions to this of course. As is the case in New Mexico and Oregon additional mechanisms have been provided to allow entities with little or no tax liability access to the full value of the credits.
} 
specific implications. However, state tax incentives typically are not enough to support renewable energy development without other state or federal incentives. Therefore, interactions that offset other options or force choices between a state tax incentive and other state or federal incentives generally should be minimized.

Design tax incentives to be goal specific. Motivations for pursuing renewable energy vary. However, tax incentives are frequently applied as an all-encompassing, broad-based incentive. Ultimately, this approach serves the single goal of renewable energy deployment. ${ }^{44}$ A policymaker who wants to support a portfolio of technologies, provide for various project ownership structures, or pursue priorities in addition to renewable energy deployment should design tax incentives with those priorities in mind.

Evaluate the level of tax incentive required to carry out the policy goal. Many renewable energy policies are implemented without thorough consideration of their expected impact on a given technology. Careful market research that studies the value of existing policies helps a policymaker determine the actual tax incentive amount required to achieve a specific goal.

Ensure that the term of the incentive fits the goal of the policy. A specific renewable energy policy may be put in place for various reasons. Stimulating an emerging industry is one possible justification. In this case, the tax credit must provide market certainty for enough time to encourage developers and manufacturers to invest in a specific state. Depending on the risk associated with a given investment, a multiyear tax incentive may be required to provide the market stability necessary to attract manufacturing investment.

Though the federal PTC for wind power has been frequently renewed the past decade, it historically has failed to provide the market certainty necessary to facilitate development of a durable wind industry (Wiser et al.2007). Given this, a longer eligibility period (5-10 years) may be appropriate if the goal for a specific tax incentive program is the development of a viable long-term industry. In other cases, a shorter eligibility period may be appropriate.

Create an outlet for individuals with limited or zero tax liability. Entities without sufficient tax liability pose a problem for tax policy intended to incentivize renewable energy investment. Schools, nonprofits, tribes, and government all have zero tax liability; therefore, these entities often do not benefit from tax policy that incentivizes renewable energy. This barrier is especially challenging at the state level because individuals or businesses must have the specific state tax liability where the renewable energy system is located. Policy provisions that allow tax credit transfers or make specific tax incentives refundable increase the value of the incentive across sectors.

\footnotetext{
${ }^{44}$ It may also result in windfall profits for the best projects and most mature technologies while only providing marginal support to technologies that are not at the same point in the technology diffusion curve and/or projects targeting a less valuable resource.
} 


\section{Conclusions}

State tax incentives are policy tools used to enhance deployment of renewable energy technologies. A few attributes of state tax incentives make them an appealing tool for increasing growth in the renewable energy sector. They can be used in various applications and designed with flexibility. Moreover, they do not require specific authorization of funds.

Given the milieu of existing policies and incentives for renewable energy development, policymakers generally use state tax incentives to complement and support existing policies. This means that state tax incentives are well positioned to provide an incremental incentive that addresses a specific state or local market barrier to renewable energy deployment. When deployment is enhanced, state tax incentives can support overarching policy goals of the environment, economic development, and energy security.

Critical design challenges for state tax incentives include:

- Insufficient tax liability (which may be addressed with a pass-through option or refundable tax credit),

- The possibility of increased federal tax burden,

- Their inability to service project debt,

- The difficulty of designing specific differentiated incentives for individual technologies.

Important design considerations include:

- Understanding how a proposed tax incentive interacts with existing incentives,

- Ensuring the level of the incentive and the term of the program are in line with broader renewable energy goals as well as individual technology goals,

- Creating a mechanism that allows entities with little or zero tax liability access to the incentive.

Well-designed tax incentives can expect to have a supporting impact on renewable energy markets. However, the scale of the impact will be tied to the incentive's magnitude and purpose. 


\section{References}

(n.d.). Retrieved January 2009, from Database of State Incentives for Renewable Energy and Energy Efficiency: http://www.dsireusa.org/

Ault, W. (May 2006). "Property Taxation of Wind Generation Assets." North American Windpower (3:4); pp. 31-34.

Bird, L.; Parsons, B.; Gagliano; T.; Brown, M.; Wiser, R.; Bolinger, M. (2003). "Policies and Market Factors Driving Wind Power Development in the United States." NREL/TP620-34599. Golden, CO: National Renewable Energy Laboratory.

Dillard, S. (April 2006). The Oregon Department of Energy Tax Credits. Retrieved March 6, 2009, from Environmental Protection Agency (EPA):

http://www.epa.gov/cleanenergy/documents/stateforum/04_20 06/4 2006 OR Tax Credits Dillard.pdf

Grover, S.; Josephson, A.; Boroski, J. (2007). Economic Impacts of Oregon Energy Tax Credit Programs in 2006 (BETC/RETC). Portland, OR: ECONorthwest.

Grover, S.; Josephson, A.; Boroski, J.; Smith, J. (2009). Economic Impacts of Oregon Energy Tax Credit Programs in 2007 and 2008 (BETC/RETC). Portland, OR:

ECONorthwest.

Hansen, J. (November 2008). Facilitator, Nebraska Wind Working Group; President, Nebraska Farmers Union.

Merrill, B. (February 2009). Oregon Department of Energy.

Nebraska Department of Revenue (NE DOR). (April 2009). Current Local Option Sales and Use Tax Rates. Retreived September 2, 2009, from http://www.revenue.ne.gov/question/sales.html

McDiarmid, M. (January 28, 2009). New Mexico Energy, Minerals and Natural Resources Department.

Oregon Department of Energy (ODOE). (March 2008). Oregon Business Energy Tax Credit. Retrieved March 6, 2009, from http://www.oregon.gov/ENERGY/CONS/BUS/docs/betcbro.pdf

Oregon Department of Energy. (August 2006). Oregon Residential Energy Tax Credit. Retrieved March 6, 2009, from http://www.oregon.gov/ENERGY/CONS/RES/tax/docs/retcbro.pdf

Residential Energy Tax Credits. (n.d.). Retrieved March 6, 2009, from Oregon Department of Energy: http://www.oregon.gov/ENERGY/CONS/RES/RETC.shtml

Thomas, C. (February 9, 2009). Tax Law Conferee, Nebraska Department of Revenue. 
Wiser, R.; Bolinger, M.; Barbose, G. (2007). Using the Federal Production Tax Credit to Build a Durable Market for Wind Power in the United States. LBNL-63583. Berkeley, CA: Ernest Orlando Lawrence Berkeley National Laboratory. 


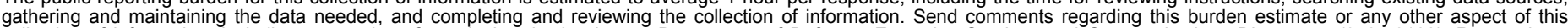

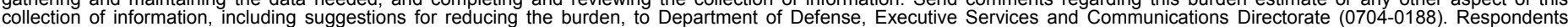

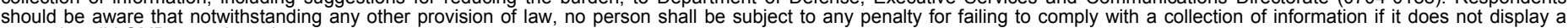

chould be aware that notwithstanding

PLEASE DO NOT RETURN YOUR FORM TO THE ABOVE ORGANIZATION.

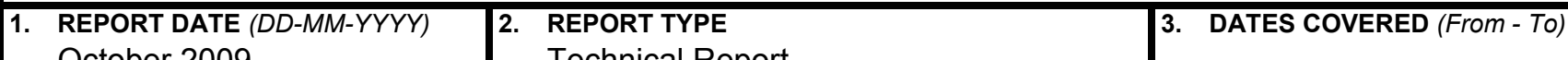
October 2009

Technical Report

4.
TITLE AND SUBTITLE
State Clean Energy Policies Analysis (SCEPA): State Tax Incentives

5a. CONTRACT NUMBER

DE-AC36-08-GO28308

5b. GRANT NUMBER

5c. PROGRAM ELEMENT NUMBER

6. AUTHOR(S)

E. Lantz and E. Doris

5d. PROJECT NUMBER

NREL/TP-6A2-46567

5e. TASK NUMBER

IGST.9000

5f. WORK UNIT NUMBER
7. PERFORMING ORGANIZATION NAME(S) AND ADDRESS(ES)

National Renewable Energy Laboratory

1617 Cole Blvd.

Golden, CO 80401-3393

9. SPONSORING/MONITORING AGENCY NAME(S) AND ADDRESS(ES)
8. PERFORMING ORGANIZATION REPORT NUMBER

NREL/TP-6A2-46567

10. SPONSOR/MONITOR'S ACRONYM(S) NREL

11. SPONSORING/MONITORING AGENCY REPORT NUMBER

12. DISTRIBUTION AVAILABILITY STATEMENT

National Technical Information Service

U.S. Department of Commerce

5285 Port Royal Road

Springfield, VA 22161

\section{SUPPLEMENTARY NOTES}

\section{ABSTRACT (Maximum 200 Words)}

As a policy tool, state tax incentives can be structured to help states meet clean energy goals. Policymakers often use state tax incentives in concert with state and federal policies to support renewable energy deployment or reduce market barriers. This analysis used case studies of four states to assess the contributions of state tax incentives to the development of renewable energy markets. State tax incentives that are appropriately paired with complementary state and federal policies generally provide viable mechanisms to support renewable energy deployment. However, challenges to successful implementation of state tax incentives include serving project owners with limited state tax liability, assessing appropriate incentive levels, and differentiating levels of incentives for technologies with different costs. Additionally, state tax incentives may result in moderately higher federal tax burdens. These challenges notwithstanding, state tax incentives that consider certain policy design characteristics can support renewable energy markets and state clean energy goals. The scale of their impact though is directly related to the degree to which they support the renewable energy markets for targeted sectors and technologies. This report highlights important policy design considerations for policymakers using state tax incentives to meet clean energy goals.

15. SUBJECT TERMS

state tax incentives; financial incentives; policy tools; state policies; policy design; state clean energy goals; renewable energy deployment; renewable energy development; renewable energy policy; renewable energy markets; market barriers; case studies; case study; Kansas; Oregon; Nebraska; New Mexico; tax liability; tax liabilities; incentive levels

\section{SECURITY CLASSIFICATION OF:}

\section{a. REPORT}

Unclassified

\begin{tabular}{|l|l}
\hline b. ABSTRACT & c. THIS PAGE \\
Unclassified & Unclassified
\end{tabular}

\begin{tabular}{l|l} 
17. LIMITATION & 18. NUMBER \\
OF ABSTRACT & OF PAGES \\
UL &
\end{tabular}

19a. NAME OF RESPONSIBLE PERSON

19b. TELEPHONE NUMBER (Include area code) 